\title{
The Implications of Climate Variability on Market Gardening in Santa Sub-Division, North West Region of Cameroon
}

\author{
Amawa Sani Gur ${ }^{1}$, Jude Ndzifon Kimengsi ${ }^{2}$, Tata Emmanuel Sunjo ${ }^{1} \&$ Azieh Edwin Awambeng ${ }^{1}$ \\ ${ }^{1}$ Department of Geography, University of Buea, P.O. Box, 63, Buea, Cameroon \\ ${ }^{2}$ Department of Geography \& Environmental Studies, Catholic University of Cameroon Bamenda (CATUC), P.O. \\ Box 782, Bamenda, Cameroon \\ Correspondence: Jude Ndzifon Kimengsi, Department of Geography \& Environmental Studies, Catholic University \\ of Cameroon Bamenda (CATUC), P.O. Box 782, Bamenda, Cameroon. Email: ukjubypro2@yahoo.com
}

Received: January 5, 2015 Accepted: January 19, 2015 Online Published: March 6, 2015

doi:10.5539/enrr.v5n2p14

URL: http://dx.doi.org/10.5539/enrr.v5n2p14

\begin{abstract}
If Cameroon maintains its position as the "bread basket" of the Central African sub-Region, one of the areas to be credited is the Santa Sub-Division which is one of the major agricultural production basins, particularly market gardening. Apart from grappling with the conventional pre and post-harvest problems which plague the agricultural sector in Cameroon, observed variability in climate has aggravated the scenario. Using climatic records temperature and rainfall) for a 10 year period, including the output of market garden crops (carrots, leeks, tomatoes and cabbage), complemented by field observations and interviews, we established a correlation between climatic variations and variations in output of market garden crops The results showed both direct and inverse relationships between climate variability and market gardening resulting in differential implications for market gardeners. The implications of this results is that in the future, market gardeners could logically shift their focus to some specific crops; this could reduce the output of these crops leaving a bearing on demand and price. As a logical way forward, we suggest some adaptation options which can help farmers to "climate -proof" the market gardening sector which remains a source of livelihood for many farmers in Santa Sub-Division.
\end{abstract}

Keywords: climate variability, market gardening, adaptation, livelihood, Santa Sub-Division

\section{Introduction}

Over the years, climatic conditions in many parts of the world have been characterised by increasing fluctuations with severe implications on a number of human activities especially agriculture. Such effects are very pronounced in developing countries which dominantly practice rainfed peasant agriculture. Yet, agriculture constitutes the backbone of these countries especially the economies of Sub-Saharan Africa given that besides ensuring the sustainability of rural livelihoods, it is also a major contributor to the Gross Domestic Product (GDP). In most countries of Sub-Saharan Africa, about 60 percent of the economically active population works in the agricultural sector. Any improvement in this sector would tantamount to an increase in rural incomes and purchasing power of a large number of the population in the region. This would reduce poverty and hunger, and ensure sustainable development (IFPRI, 2006). While over $85 \%$ of the rural population of Sub Saharan Africa continues to rely on agriculture for their survival (Mahendra et al. 2008), climatic variations have been the bane of economic development in this region as they largely depend on rain-fed agriculture for their survival (Odingo, 2008). These less resilient and vulnerable agricultural populations continue to bear the brunt of climate change. Reducing soil moisture and atmospheric humidity are among the most devastating effects of climate variability and change and this has succeeded to disrupt food crop output (including market garden cops) thus signaling threats to food security (Odingo, 2008).

Climatic oscillations in the less developed countries are uncertain and all these have a significant impact on man and his livelihood.(World Bank, 2006). This has caused most of the developing nations including Cameroon to be unable to meet up with the Millennium Development Goals. In fact, climate change is considered as posing one of the greatest challenges to agriculture and food security in Sub-Saharan Africa (SSA). This is because the region's coping capacity to climate change is perceived to be very low (Odingo, 2008). 
In Cameroon, agriculture remains the backbone of the country's economy and employs more than $70 \%$ of its population. Cameroon produces both export and food crops through government corporations like the Cameroon Development Corporation (CDC) or by individuals who carryout peasant agricultural production. However, this activity has been largely affected by oscillations in the local climatic elements especially rainfall and temperature which have effects on both plantation and peasant agriculture (Molua \& Lambi, 2006; Kimengsi \& Muluh, 2013; Kimengsi \& Tosam, 2013).

Market gardening is carried out on an all year round basis. It entails the cultivation of highly perishable crops which are consumed and or transformed within a relatively short period of time. In Cameroon, market gardening is practiced on the Bamboutos Highlands, the slopes of Mount Cameroon, the Mungo and Benue Depressions, the Foumbot plains and the Bamenda Highlands, including Santa Sub-Division. The principal crops include green beans, carrots, lettuce, cucumber, cabbages, spices and vegetables under ample precipitation conditions (Jalo, 2008). If Cameroon maintains its position as the "bread basket" of the Central African Sub - Region today, one of the areas to be credited for this is the Santa Sub- Division. This is because the food produced in Santa Sub-Division especially market garden crops) is not only consumed in the North West Region and other parts of Cameroon, but far beyond to other countries (Alangeh, 2013).

Among the sectors that have borne the greatest brunt of these climatic variations is perhaps the market garden sector. Variation in major climatic elements especially rainfall pattern and temperature have significantly affected agriculture in general and market gardening in particular especially in the Santa highlands of Cameroon which enjoys a relatively temperate sub-climatic conditions amidst the broad tropical climatic system. It is an agricultural practice on relatively smaller farm sizes but characterised by the intensive application of inputs like chemicals, fertilizers, and the use of genetically modified seedlings to increase production alongside widespread use of irrigation waters especially during the dry season when variability in climatic conditions is high.

\section{The Problem}

Santa sub division contributes in no small measure to food security in the Central African sub Region. Market gardening is a very important farming type in Santa as it is a major livelihood activity of the people in terms of the income, employment and sustenance if offers. Apart from grappling with the conventional pre and post-harvest problems which plague the agricultural sector, observed variability in climate has added to the scenario. Variations in temperature and rainfall on a seasonal and annual basis for a 10 year period (2001 to 2011) have an effect on market gardening crops (tomatoes, carrots, cabbage and leeks). However, it should be noted that the effects of these variations vary with respective crops indicating both direct and inverse relationships. The inability of the people to master and cope with variability in climate has been a major setback to current and future market gardening in Santa. This has an implication on the coping strategies, crop production, demand and supply within and out of the country as well as on the livelihood of the market gardeners. This study has a main objective to examine variability in climate for Santa subdivision and its implications for market gardening.

\section{Literature Review}

Much exist in the literature on climate variability both long and short term) and agriculture:

Lordemann and Salas (2009) maintain that it is not surprising that agriculture, as an important economic activity is expected to be vulnerable to climate variability and change; it remains the most vulnerable activity to extreme climate change since her impact on economic growth is significant, especially in the short and mid-term - when agricultural production decreases and prices increase. They further indicate that there is strong evidence that climate change leaves sequels in the agricultural production function. Therefore, it seems obvious that any significant alteration of climatic parameters on a global scale should impact local agriculture, and therefore affect the world's food supply (Rosenzweig \& Hillel, 1995). The vulnerability of agriculture to climate variability and change has received much attention in the international scientific community as reflected in Article 2 of the United Nations Framework Convention on Climate Change (UNFCCC), which calls for the stabilization of greenhouse gas concentrations in the atmosphere at a level that would prevent serious anthropogenic interference with the climate system. Such a level, the convention notes, should be achieved within a time frame sufficient to allow ecosystems to adapt naturally to climate change, ensure that food production is not threatened, and ensure sustainable economic development (Lordemann \& Salas, 2009).

Studies have gone into questions of just how farming systems (including market gardening) might be affected by climatic variations in different regions, and by how much; and whether the net result may be harmful or beneficial, and to whom. Several uncertainties limit the accuracy of current projections on the future impacts of climatic caprices on agriculture (Rosenzweig \& Hillel, 1995). One of these uncertainties relates to the degree of temperature increase and its geographic distribution, another pertains to the concomitant changes likely to occur 
in the precipitation patterns that determine the water supply to crops, and to the evaporative demand imposed on crops by the warmer climate. The variable nature of climate may present crop production with prospects for both benefits and drawbacks. It is imperative to evaluate the losses that could result from the effects of such variability and to enlighten farmers on ways of better managing this increasing unpredictability (Rosenzweig \& Hillel, 1995).

The impact of climate variability and change on crop farming in Cameroon has received considerable scholarly attention (Molua \& Lambi, 2006; Lambi \& Molua, 2007; Kimengsi \& Muluh, 2013; and Kimengsi \& Tosam, 2013). For instance, Lambi and Molua (2007) attributed the observed fluctuations in the prices of Cameroon's export crops to the vagaries of the weather. Based on a farm-level survey of more than 800 farms, they employed a Ricardian cross-sectional approach to measure the relationship between climate and the net revenue from crops in which they arrived at a conclusion that net revenues fall as precipitation decreases or temperatures increase across all the surveyed farms. Their empirical analysis also reveal that a $2.5^{\circ} \mathrm{C}$ increase in temperatures would cause net revenues from agriculture in Cameroon to drop by $\$ 0.5$ billion, and a $5^{\circ} \mathrm{C}$ increase would cause net revenues to fall by $\$ 1.7$ billion. Similarly, a $7 \%$ and $14 \%$ decrease in rainfall would cause net revenues from crops to fall by $\$ 1.96$ billion and $\$ 3.8$ billion respectively.

Faced with the complicated scenario of increasing climate variability which affects the livelihoods of much of the farming populations in Sub-Saharan Africa, there is a need for the development of appropriate strategies for reducing the vulnerability of farmers to rain fed agriculture. This could be achieved by helping local farmers to use their local knowledge in combination with innovations to enhance local adaptations to climate change and variability (Mongi et al., 2010). Adaptation has become the buzzword in climate change discussions today and may either be autonomous or planned. Autonomous adaptation, is the reaction of, for example, a farmer to changing precipitation patterns, in that he or she changes crops or uses different harvest and planting/sowing dates, while planned adaptation measures are conscious policy options or response strategies, often multi-sectoral in nature, aimed at altering the adaptive capacity of the agricultural system or facilitating specific adaptations (FAO, 2007). For example, deliberate crops selection and distribution strategies across different agro-climatic zones, substitution of new crops for old ones and resource substitution induced by scarcity (Easterling, 1996). Enabling small farmers to adapt to impacts of climate change requires making access to knowledge and information essential. This is especially important considering projections that poor countries, which generally have the least level of technological innovation, will be hit hardest by climate change. New ways of sharing innovation and information between private and public sectors to deliver technologies that enable adaptation (and mitigation) must be developed in the next few decades (Ludi et al., 2007). In another dimension, insurance mechanisms provided through markets or in public-private partnerships might become more important in future. Weather-indexed crop insurance practices are currently tested in some countries and they may be helpful to farmers who face more volatile weather events. Weather-indexed insurance pays out to farmers, based not on their yield losses, but on specific, local weather-related benchmarks (IFPRI, 2006).

\section{Research Site, Materials and Methods}

Santa is one of the 32 sub divisions of the North West Region which is located between latitudes $5^{\circ} 42^{\prime}$ and $5^{\circ}$ $53^{\prime}$ North of the Equator and longitudes $9^{\circ} 58^{\prime}$ and $10^{\circ} 18^{\prime}$ East of the Greenwich Meridian (Santa Rural Council Monographic Study, 2003). It covers some nine villages, namely, Mbei, Njong, Akum, Mbu (Baforchu), Alatening, Baba II, Awing, Baligham ,and Pinyin. Located in the in the Western Highlands of Cameroon, it covers a surface area of about $532.67 \mathrm{~km}^{2}$. It is bordered to the North by Bamenda Sub Division, to the West by Bali and Batibo Sub-Divisions, to the South by Wabane, Babadjou and Mbouda and to the East by Galim. It lies some $20 \mathrm{~km}$ from Bamenda and is disenclaved by the national road number 10 which links Bamenda to Bafoussam and the rest of the country and sub-region.

\subsection{Data Collection}

Primary data was obtained through the interview of 50 market gardeners who were randomly chosen within the study area. A random sample was preferred because the pre-field studies indicated that there is a high degree of homogeneity in terms of the farmers' characteristics. Therefore, it was concluded that the views expounded by the 50 randomly chosen farmers could represent the views of market gardeners in the area. In addition, field observations were done in some identified farms. Climatic data (rainfall and temperature) were obtained from the North West Regional Delegation of Transport, data on market gardening crop production which were gotten from the Sub Divisional Delegation of Agriculture and Rural Development for Santa while other baseline information was obtained from the Santa Council. Presentation and analysis made use of an integrated approach assuming the form of tables, maps, and graphs. In other to draw conclusions on climate variability in Santa, the coefficient of 
variation was used to determine variability on an annual and seasonal basis for temperature and rainfall. The Pearson's Product Moment Correlation was used to show the relationship between climate variability and the four identified market garden crops considered (tomatoes, cabbage, carrots and leeks) at 95\% significance (T-test) level.

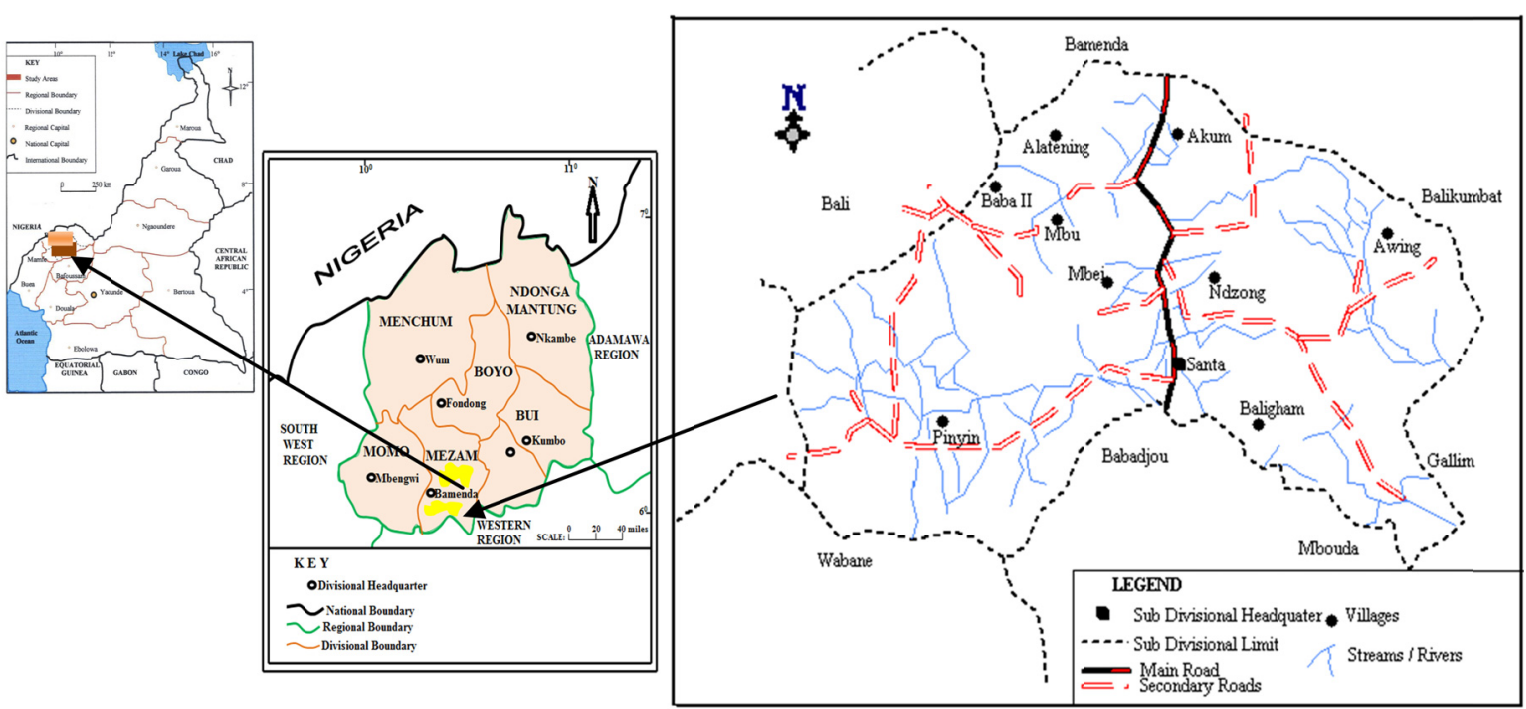

Figure 1. Location and layout of Santa Sub-Division

Source: Santa Rural Council Monographic Study (2003).

\section{Presentation of Results}

\subsection{Climate Variability in Santa: Seasonal and Annual Variability in Rainfall}

The agricultural calendar in Santa Sub-Division is strongly influenced by the pattern of rainfall and temperature especially by their seasonality (Figure 2) and annual variations (Figure 3). Market garden crop cultivation depends on the pattern of rainfall as it provides the moisture and water for plant growth. Intense agricultural activities are pronounced in this Sub-Division as the growing population is engaged in market gardening.

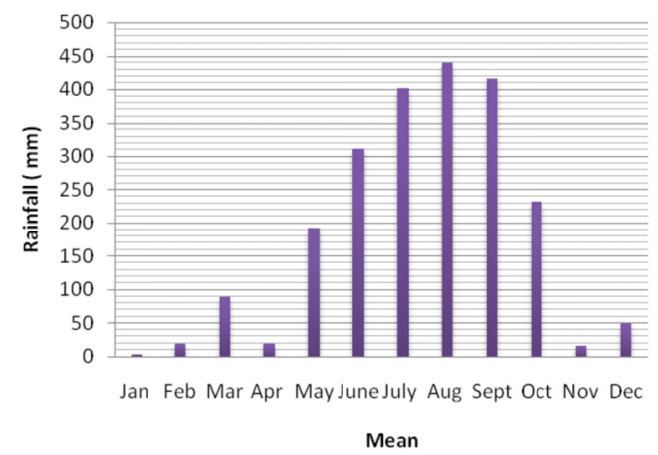

Figure 2. Mean Monthly Rainfall in Santa

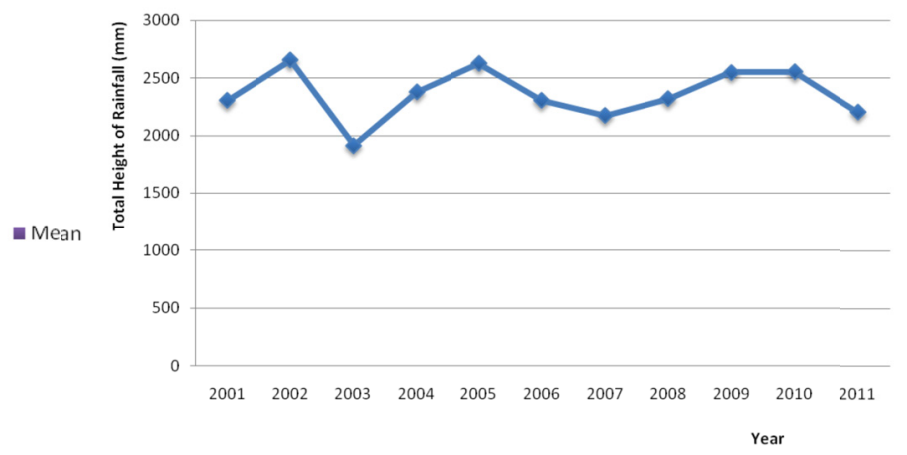

Figure 3. Annual Rainfall pattern in Santa

Annual rainfall patterns significantly influence the pattern of distribution of market gardening in Santa. Santa's annual rainfall conditions show high spatial variability. The highest mean annual rainfall for 2012 is $2555.7 \mathrm{~mm}$ while the lowest annual rainfall total was $1883.5 \mathrm{~mm}$ (Figure 3). These annual averages have a significant impact on market gardening since changes in agricultural crop yields are well known to depend on the weather 


\subsection{Seasonal Rainfall Variations}

These seasonal excesses or deficiencies in rainfall (Figure 4) bring about disparity in inputs. However, crops are cultivated all year round. During the dry season, the amount of water from rainfall is extremely low and cannot support market gardening. Consequently, market gardening farmers resort to the use of irrigation using water from nearby streams for crop cultivation. Rainfall in the dry season is low, thus the number of people involved in dry season farming depend on irrigated water from nearby streams for crop cultivation. Rainfall is fairly distributed in the wet season but with high variations. This brings about uncertainty in the planting season.

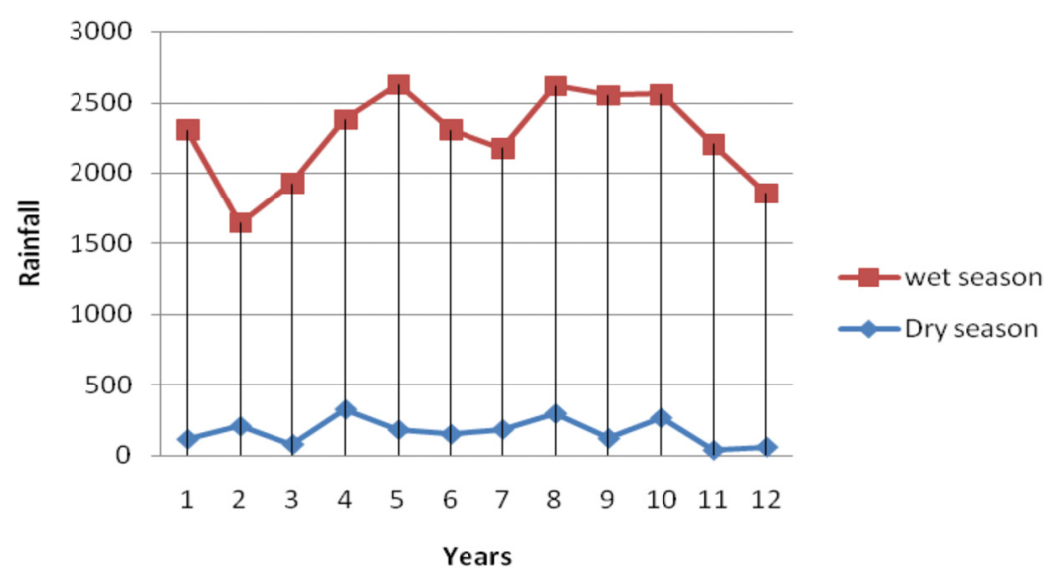

Figure 4. Seasonal rainfall variations in Santa

In order to determine variability in rainfall, the coefficient of variation or deviation from the mean for the 11 year period $(2001-2012)$ is used (Table 1).

Table 1. Coefficient of variation for rainfall in Santa sub-division

\begin{tabular}{cccc}
\hline Year & Annual rainfall & $\left(\mathrm{x}^{-} \mathrm{x}^{-}\right)$ & $(\mathrm{x}-\bar{x})^{2}$ \\
\hline 2001 & 2306 & 0.25 & 0.0625 \\
2002 & 2554.8 & 249.05 & 62025.9025 \\
2003 & 1914.6 & -391.115 & 152998.3225 \\
2004 & 2376.7 & 70.95 & 5033.9025 \\
2005 & 2625.5 & 319.75 & 102240.0625 \\
2006 & 2305.4 & -.0 .35 & 0.1225 \\
2007 & 2173.6 & -132.15 & 17463.6225 \\
2008 & 2221.3 & -844.5 & 7131.8025 \\
2009 & 2550.1 & 244.35 & 59706.9225 \\
2010 & 2555.7 & 249.95 & 62475.0025 \\
2011 & 2201.8 & -103.95 & 10805.6025 \\
2012 & 1883.5 & -422.25 & 178295.0625 \\
& $\sum \mathrm{x}=27669$ & \multicolumn{2}{|}{$\sum\left(\mathrm{x}-\bar{x}^{2}\right)=658176.9525$} \\
& $\bar{x}=2305.75$ & & \\
\hline
\end{tabular}

Santa's annual rainfall variability is shown by a CV of $10.89 \%$. Generally a coefficient of variation of less than $10 \%$ is a clear indication that there is minimal fluctuation in the amount of rainfall on an annual basis implying that the rainfall is reliable for crop cultivation. The CV of $10.89 \%$ is an indication that there is substantial fluctuation in the pattern of rainfall. This figure gives a more generalized picture of the situation and calls for the need to assess variability on a seasonal basis. 


\subsection{Dry and Wet Season Variability}

Table 2 shows calculations of the wet and dry season variations using the CV. The seasonal variability picture shows a situation of less variability in rainfall (9.35\%) for the wet season and high variability $(49.37 \%)$ for the dry season. Hence rainfall is more reliable in the wet season than the dry season (Table 2).

Table 2. coefficient of variation of rainfall for the wet and dry season in Santa

\begin{tabular}{lllllll}
\hline Year & Dry season(x) & Wet season(y) & $(x-\bar{x})$ & $(\mathrm{x}-\bar{x})^{2}$ & $\mathrm{y}^{-} \mathrm{y}^{-}$ & $\left(\mathrm{y}-\mathrm{y}^{-}\right)^{2}$ \\
\hline 2001 & 115.6 & 2190.4 & -53.5 & 2862.25 & 14 & 196 \\
2002 & 207 & 2447.8 & 379 & 1436.41 & 271.4 & 7365.96 \\
2003 & 79.3 & 1844.6 & -89.8 & 8064.04 & -331.8 & 110091.24 \\
2004 & 325.5 & 2051.2 & 156.4 & 24460.96 & -125.2 & 15675.04 \\
2005 & 182.7 & 2442.8 & 13.6 & 184.96 & 266.4 & 70968.96 \\
2006 & 150.9 & 2154.5 & -18.2 & 331.24 & -21.9 & 479.61 \\
2007 & 184.3 & 1989.3 & 15.2 & 231.04 & -187.1 & 35006.41 \\
2008 & 295.8 & 2321.3 & 126.7 & 16052.89 & 144.9 & 20996.01 \\
2009 & 122.1 & 2428 & -47 & 2209 & 251.6 & 15.87 \\
2010 & 265.8 & 2289.9 & 96.7 & 9350.89 & 113.5 & 12882.25 \\
2011 & 38.8 & 2163.8 & -130.3 & 16978.09 & -12.6 & 158.76 \\
2012 & 60.4 & 1793.1 & -108.7 & 11815.69 & -383.3 & 146918.89 \\
& $\sum \mathrm{x}=2028.2$ & & & $\sum(\mathrm{x}-\bar{x})^{2}=93977.46$ & & $\sum\left(\mathrm{y}-\mathrm{y}^{-}\right)^{2}=497047$ \\
\hline
\end{tabular}

variability in the incidence of rainfall over the years affect agricultural production in general and market garden crops production in particular as their output tends to fluctuate with periods of high and low rainfall amounts. This implies that it pays to engage in market gardening in the wet than dry season.

In the case of the dry season, some implications are noted especially with regards to a drop in crop output and an increase in their prices. Here, farmers are considering the increasing adoption of irrigation to increase yields, and the cultivation of market gardening crops around watersheds; which, in the near future, could introduce the problem of watershed degradation.

\subsection{Seasonal and Annual Variability in Temperature}

Temperature is an important climatic factor that affects market gardening in Santa Sub-Division. This is because temperature variability tends to determine the germination, early growing, flowering and fruiting as well as maturity of market garden crops such as carrots, tomatoes, lettuces and green beans. Thus it is one of the major determinants of the rate of growing. Market gardening crop production in Santa Sub-Division is booming because Santa has a temperature that is mild and favours the cultivation of these crops. High temperatures are experienced in the dry season especially between December and April (Figure 6). The rate of increase is significant and crops in terms of their physiological changes have been very sensitive to this increase. The increase in minimum temperature threatens the market gardening sector. The temperature is increasing although there is a great fluctuation around the mean. This is confirmed by the seasonal and annual variability (Table 3).

\subsection{Temperature Variability and Coefficient of Variations}

Table 3 shows standard deviations and coefficients of variations of temperature for Santa.

By analyzing 10 years of temperature data (2001-2010), the coefficient of variation was found to be $18.6 \%$ and the mean of $17^{\circ} \mathrm{C}$. These results show that there is variation in the temperature of Santa over the observed period. Temperature variations of $18.6 \%$ may not have a significant impact on market garden crop production in the Santa Municipality. 


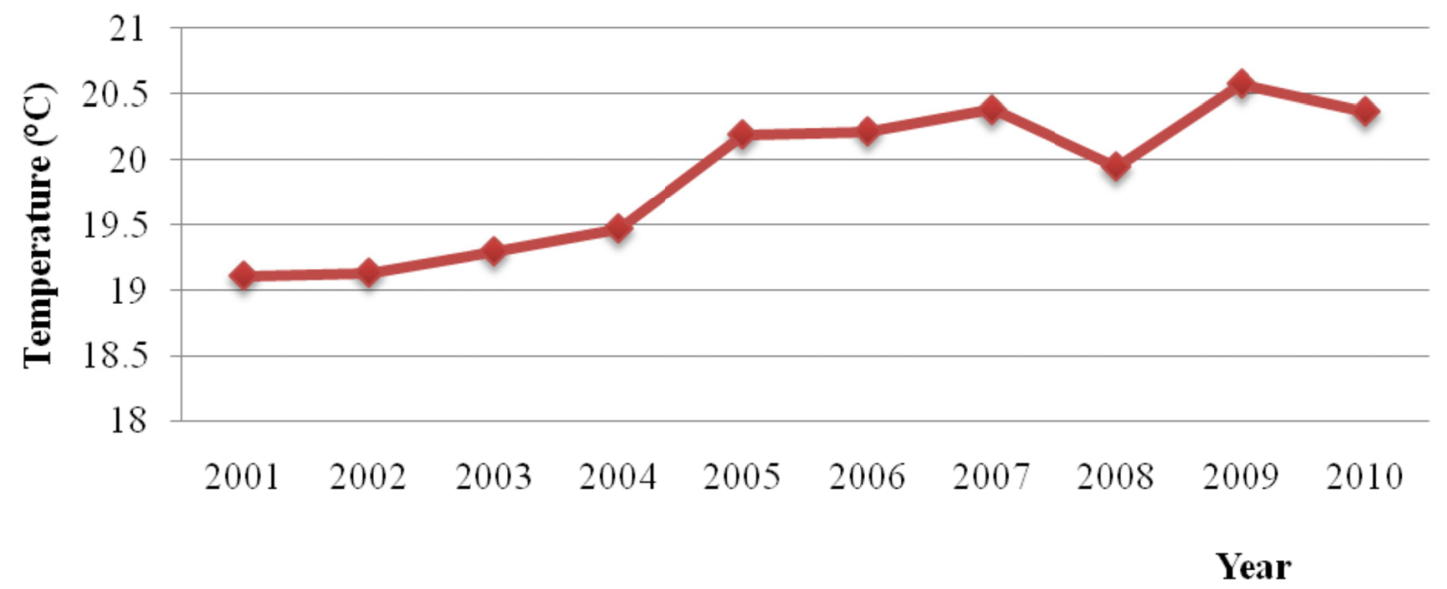

Figure 6. mean annual temperatures in Santa

Regional Delegation of Transport Bamenda (2013).

Table 3. coefficient of variation of temperature for Santa sub-division

\begin{tabular}{lllll}
\hline Year & Annual temperature & $(\mathrm{x}-\mathrm{x})$ & $(\mathrm{x}-\mathrm{x})^{2}$ \\
\hline 2001 & 19.6 & -2.6 & 6.76 \\
2002 & 19.09 & -2.09 & 4.36 \\
2003 & 19.1 & -2.1 & 4.41 \\
2004 & 19.3 & -2.3 & 5.29 \\
2005 & 20.3 & -3.3 & 10.89 \\
2006 & 19.3 & -2.3 & 5.29 \\
2007 & 21.3 & -4.3 & 18.49 \\
2008 & 21.3 & -2.1 & 8.41 \\
2009 & 19.9 & -4.9 & 24.01 \\
2010 & 20.4 & -3.4 & 11.56 \\
\hline
\end{tabular}

$(\mathrm{CV})=18.6 \%$.

\subsection{Implications of Climate Variability on Market Gardening}

Output for the main market garden crops (tomatoes, carrots, cabbages and leeks) were analyzed and the variations coincide with variations in the different climatic parameters within the 10 year period. To statistically analyze the implications of temperature and rainfall on market gardening in Santa Sub-Division, the Product Moment Correlation was employed to establish a correlation for three years $(2010$ - 2012). The Pearson's Correlation Coefficient was used to find out the relationship between the variables (rainfall and temperature) and market gardening crop yields. This method has been applied by some researchers (Lamal and Emaku 2007) in an effort to determine the interrelationship between climatic variables and crops yields. Correlation coefficient values range from -1.00 to +1.00 . The value of -1.00 represents a perfectly negative correlation while a value of +1.00 represents a perfectly positive correlation and the value of 0.00 represents the lack of correlation (State Soft, Inc, 1997). The results of the correlation show that the climatic parameters considered affect market gardening both positively or negatively (Table 4 ).

Table 4. Correlation analysis of climatic variabilitye and crop yields

\begin{tabular}{lll}
\hline Crops & Rainfall & Temperature \\
\hline Tomatoes & -0.490 & -0.730 \\
Carrots & 0.439 & 0.600 \\
Cabbage & -0.225 & -0.669 \\
Leeks & 0.270 & 0.890 \\
\hline
\end{tabular}

Correlation significance at the 0.05 level (2 tailed tests). 


\subsection{Relationship Between Temperature and Market Gardening}

Temperature demonstrates a very strong negative relationship with tomatoe and cabbage yields in Santa at $(-0.730)$ and $(-0.669)$ respectively. This implies that, tomatoe and cabbage yields significantly decrease with increases in temperatures. Temperature shows a strong positive relationship with carrots $(+0.600)$ and leeks $+(0.890)$, an indication that they are favoured by increasing temperatures. The implication of this result is that if the future scenario presents a situation of increasing temperatures, there could be a logical shift of focus to leeks and carrots while in the same vein, decreasing temperatures could encourage the concentration of market gardeners on cabbage and tomatoes. This could reduce the output of these crops affecting supply and and price.

\subsection{Relationship Between Rainfall and Market Gardening}

Rainfall within Santa Sub-Division has been characterized by high fluctuations in the period under consideration (2001-2011). Rainfall within the area fluctuates with seasons and as a result plays a significant role on market garden crop cultivation in Santa. The correlation coefficient analysis reveals that rainfall shows a very weak negative relationship (inverse) with cabbage yield (-0.225). This implies that, as rainfall increases above a threshold of $3000 \mathrm{~mm}$ per annum, cabbage yields turn to decrease. Secondly, rainfall shows a strong positive relationship with carrot (0.439). This implies that, as rainfall increases, carrot yields also increase. Rainfall also demonstrates a weak positive relationship with leeks $(+0.270)$ implying that it has very little to contribute in ensuring an increase in leeks production. Finally, rainfall shows a strong negative relationship with tomatoes yields $(-0.490)$.

A comparative analysis of the correlations show that some crops are more water demanding (carrots, leeks, tomatoes) whiles others are not (cabbage) this help to bring out meteorological differences between crop yields over the years. This notwithstanding, production can also be enhanced by other factors such as improved methods of farming and fertilizer application which are held constant in this study.

The T-test analysis of the impact of rainfall and temperature shows that at a probability level of 0.05 , rainfall has a significant effect on market gardening while no significant difference was observed in te relationship between temperature and market gardening since the expected T-value is greater than the calculated T-value (Table 5).

Table 5. Summary of T-test Results

\begin{tabular}{lccc}
\hline variables & T-calculated (t-cal) & T-Expected(t-exp) & Results \\
\hline Rainfall; Market gardening yields & 21.7 & 1.72 & t-cal $>$ t-exp \\
Temperature; Market gardening yields & -10.6 & $<1$ & t-exp $<$-cal \\
\hline
\end{tabular}

Where $\mathrm{a}=0.05$ (that is at $95 \%$ confidence interval).

Conclusively, the yields in market gardening depend to a greater extent on climate although most of the primary constraints identified by farmers were lack of general knowledge about the specific climatic conditions of crop types, low educational level of farmers, limited transportation facilities from when the crops are harvested to the market.

The implications of climate variability especially for the crops with negative relationships could be viewed from changes in crop output and the prices of these products. Between 2010 and 2012, the hectarage of tomatoes and cabbage which are not favoured by increasing temperatures reduced by $10 \%$ and $7 \%$ respectively while those for carrots and leeks (which have a positive relationship with increasing temperatures) increased by $8 \%$ and $12 \%$ respectively (Table 6). Furthermore, this has led to the continuous encroachment of the farming population, especially in the dry season into watersheds.

Table 6. Percentage change in the margins of market gardens 2010-2012 (per ha)

Source: Field Work, 2013.

\begin{tabular}{lc}
\hline Crops & $\%$ \\
\hline Tomatoes & -10 \\
Carrots & 8 \\
Cabbage & -7 \\
Leeks & 12 \\
\hline
\end{tabular}




\section{Conclusion and Recommendations}

Variations in climatic elements have been established for Santa Sub Division and both short term and long term changes in climatic variables (rainfall and temperature) have an effect on market gardening. A negative correlation exists between climate and two market garden crops (tomatoes and cabbage) implying that a minimum amount of rainfall and temperature are needed for improving market garden yields. At a probability level of $0.5(95 \%)$ rainfall has critical effect on market garden yields whereas; temperature has no significant effect on it. Temperature and rainfall demonstrates positive correlation with leeks and carrot yields. This indicates some interrelationship between temperature and market gardening crop yields.

In a bid to combat the problems arising from climate variability and its impact on market gardening in Santa and to ensure sustainable agriculture, the following recommendations are proposed:

Climate information and general agricultural knowledge about crops response to specific climate conditions should be made available to farmers and possibly interpreted because if such agro meteorological information is well understood, it will assist farmers to further plan their activities in Santa and adjust their agricultural calendar to avoid crop failures.

Furthermore, the Ministry of Agriculture and Rural Development, and Non-Governmental Organizations working in the domain of agriculture should promote the security and sustainability of water resources through monitoring mechanisms. There is a need to create an enabling environment which gives room for the smooth response to the introduction of adequate crop species as an adaptation to climate change and variability and sustaining adequate agricultural yields. Also, predictions should be released to farmers in time and coping strategies should be put in place to reduce the impact.

\section{References}

Alangeh, L. (2013). Rural/Urban Food Transportation and Sustainable Rural Livelihood: The Case of Santa Sub-Division. Unpublished DIPES II Dissertation, Department of Geography, University of Bamenda, Cameroon.

Amawa, S. G. (2009). Stream Discharge, Seasonality and Variability along the Bamenda and Adamawa Highlands (Cameroon). Journal of Applied Social Sciences, 8(1 \& 2). Unique Printers Bamenda

Easterling, W. E. (1996). Adapting North American Agriculture to Climate Change in Review. Agricultural and Forest Meteorology, 80(1), 1-54. http://dx.doi.org/10.1016/0168-1923(95)02315-1

Ekpoh, I. J. (1991). The effect of climate variability on agriculture in Nigeria. unpublished PhD thesis, the university of Birmingham UK

FAO. (2007). Adaptation to climate change in agriculture, forestry and Fisheries: Perspective, Framework and Priorities. Food and Agriculture Organization of the United Nations Rome, 2007. Retrieved from ftp://ftp.fao.org/docrep/fao/009/j9271e/j9271e.pdf

International Food Policy Research Institute, IFPRI. (2006). How will Agriculture Adapt to a Shifting Climate? In IFPRI Forum, December 2006.

Inter-governmental Panel on Climate Change, IPCC. (2007). Summary for Policymakers. Working Group II Climate Change 2007: Climate Change Impacts, Adaptation and Vulnerability. IPCC, Geneva.

Jackson, I. (1991). Climate water and agriculture in the tropics new York. Longman.

Kimengsi J. N., \& Tosam, J. N (2013). Climate Variability and Cocoa Production in Meme Division of Cameroon: Agricultural Development Policy Options. Greener Journal of Agricultural Sciences, 3(8), 606-617. August 2013. ISSN: 2276-7770.

Kimengsi, J. N., \& Muluh, N. G. (2013). A Comparative Assessment of the Effect of Climatic Variations on the Crops of the Cameroon Development Corporation (CDC): Adaptation Options. Environment and Natural Resources Research (ENRR), 3(1), 144-156. http://dx.doi.org/10.5539/enrr.v3n1p144

Lawal, J. O., \& Emaku, A. L. (2007). Evaluation of the Effect of Climatic Changes on Cocoa Production in Nigeria: Cocoa Research Institute of Nigeria (crin) as a Case Study. African Crop Science Conference Proceedings, 8, 423-426. African Crop Science Society.

Lambi, C. M., \& Molua, E. L (2007). The Economic Impact of Climate Change on Agriculture in Cameroon. World Bank Policy Research Working Paper No. 4364. Retrieved from http://papers.ssrn.com/sol3/ papers.cfm?abstract_id $=1016260$ 
Lordemann, J. A., \& Salas, T. J. A. (2009). The Climate Change Effects on the Agricultural Sector of Bolivia. Instituto de Investigaciones Socio-Económicas (IISEC), Universidad Católica Boliviana. Retrieved from http://ideas.repec.org/f/pal424.html

Ludi, E., Stevens, C., Peskett, L., \& Cabral, L. (2007). Climate Change and Agriculture: Agricultural Trade, Markets and Investment. Draft, March 2007, Overseas Development Institute.

Mahendra M. S., Fischer, G., \& Velhuizen, V. H. (2008). Food Security and Sustainable Agriculture: The Challenges of Climate Change in Sub Saharan Africa. In African Economic Research Consortium, AERC (2008): Climate Change and Economic Development in Sub Saharan Africa. Senior Policy Seminar X, Addis Ababa, Ethiopia, 7-9 April, 2008.

Molua, E. L., \& Lambi, C. M. (2006). Climate, Hydrology and water Resources in Cameroon (pp. 1-37). CEEPA Discussion Papers, Special Series on Climate Change and Agriculture in Africa. Centre for Environmental Economics and Policy in Africa (CEEPA), University of Pretoria, South Africa. Retrieved from http://www.ceepa.co.za/docs/CDPNo17.pdf

Mongi, H., Majule, A. E., \& Lyimo, J. G. (2010). Vulnerability and Adaptation of Rain Fed Agriculture to Climate Change and Variability in Semi-Arid Tanzania. African Journal of Environmental Science and Technology, 4(6), 371-381. Retrieved from http://www. academicjournals.org/

Odingo R. S. (2008). Climate Change and Economic Development - Issues, Challenges and Opportunities for Africa in the Decades Ahead. In African Economic Research Consortium, AERC (2008): Climate Change and Economic Development in Sub Saharan Africa. Senior Policy Seminar X, Addis Ababa, Ethiopia, 7-9 April, 2008.

Tearfund. (2006). Overcoming the Barriers: Mainstreaming Climate Change Adaptation in Developing Countries. Tearfund Climate Change Briefing Paper 1.

Rosenzweig, C., \& Hillel, D. (1995). Potential Impacts of Climate Change on Agriculture and Food Supply. Consequences, 1(2). Retrieved December 5, 2011 from http://www.gcrio.org/CONSEQUENCES/ summer95/agriculture.html

Watson, T. (1995). Climate Change, Impacts, Adaptation And mitigation Scientific And Technical Analysis. Cambridge University Press.

World Bank. (2010). Sustaining water for all in changing climate. World Bank Group Implementation Progress Report. Washington D C.

\section{Appendix}

Output for some market gardening crop production and climatic variables (2001-2010)

\begin{tabular}{ccccccc}
\hline Year & Tomatoes & Carrots & Cabbage & Leeks & Rainfall $(\mathrm{mm})$ & Temperature $/{ }^{\circ} \mathrm{c}$ \\
\hline 2001 & 3500 & 7000 & 7500 & 2420 & 3206 & 19.6 \\
2002 & 3700 & 7001 & 7660 & 2300 & 2654.8 & 19.01 \\
2003 & 3800 & 7210 & 7700 & 3000 & 1923.9 & 19.1 \\
2004 & 3810 & 7200 & 7234 & 3220 & 2376.7 & 19.3 \\
2005 & 3700 & 7130 & 7017 & 3500 & 2625.5 & 20.3 \\
2006 & 3162 & 7160 & 8500 & 3900 & 2305.4 & 19.3 \\
2007 & 3162 & 7630 & 6800 & 3440 & 2173.6 & 21.3 \\
2008 & 3115 & 7234 & 7040 & 3470 & 2617.1 & 19.9 \\
2009 & 3111 & 7240 & 6300 & 3886 & 2550.1 & 21.9 \\
2010 & 3208 & 7740 & 7770 & 3443 & 255.7 & 20.4 \\
\hline
\end{tabular}

Source: Compiled from Annual Reports of Sub-Regional Delegation of Agriculture and climatic Data from Regional Delegation of Transport (2013).

\section{Copyrights}

Copyright for this article is retained by the author(s), with first publication rights granted to the journal.

This is an open-access article distributed under the terms and conditions of the Creative Commons Attribution license (http://creativecommons.org/licenses/by/3.0/). 